\title{
Mindre rus etter motiverende intervju
}

\section{En til to samtaler med motiverende intervju under innleggelse i akutt- psykiatrisk avdeling førte til mindre rusbruk to år senere.}

Mange pasienter som legges inn i psykiatriske akuttavdelinger har stort rusmiddelforbruk. Innleggelsen varer gjerne bare noen dager, og mange har liten eller ingen oppfølging av rusproblemene sine etter utskrivning. Motiverende intervju er en veldoku-

mentert samtalemetode som søker å skape atferdsendring gjennom å undersøke personens egne grunner og motiver for å endre livsførsel. Først når personen blir bevisst sine egne ønsker og endringsmuligheter, kan forandring finne sted.

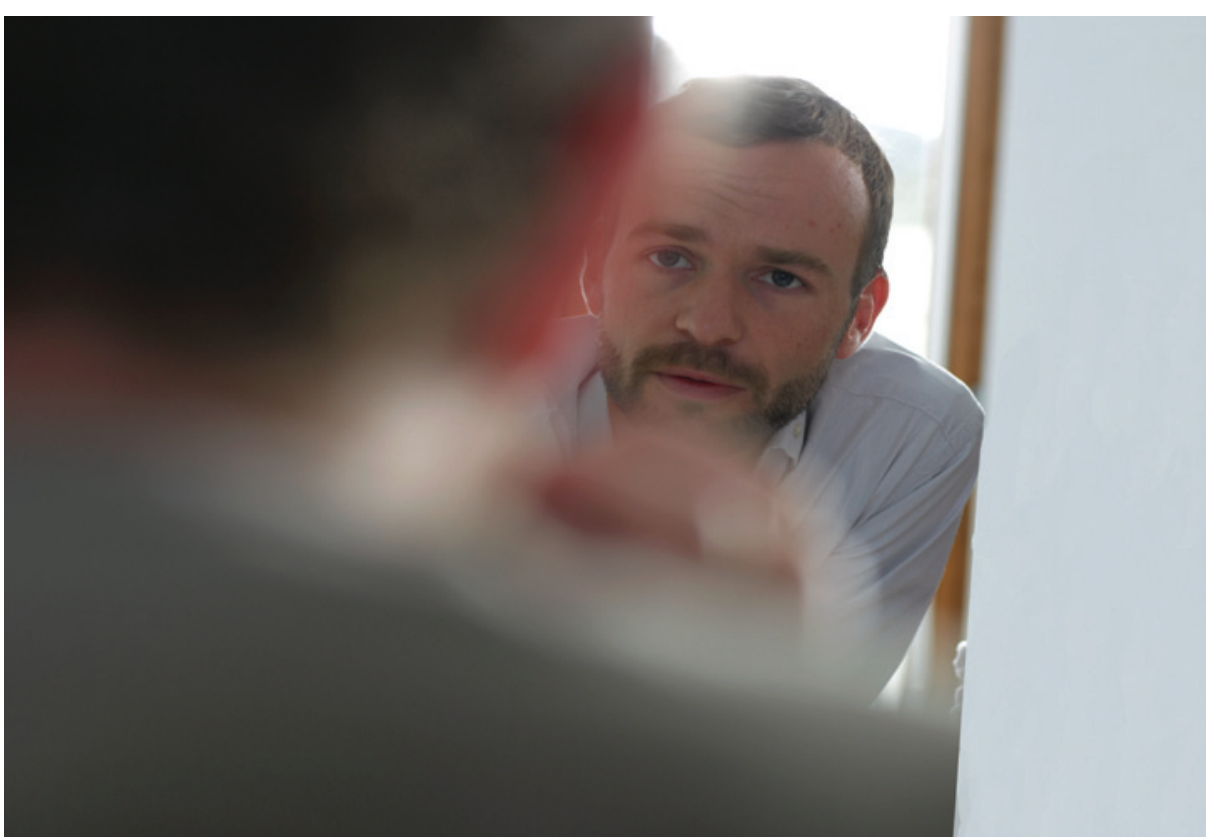

Illustrasjonsfoto Thinkstock
I en åpen randomisert kontrollert studie ved St. Olavs hospital, avdeling Østmarka undersøkte vi effekten av 1-2 korte samtaler med motiverende intervju til pasienter med rusmiddelbruk innlagt i akuttpsykiatrisk avdeling. 135 pasienter ble inkludert, hvorav 67 ble randomisert til motiverende intervju i tillegg til vanlig behandling, mens 68 kun fikk vanlig behandling. Selvrapportert rusmiddelbruk siste tre måneder ble registrert etter 3, 6, 12 og 24 måneder.

Begge gruppene rapporterte om redusert rusmiddelforbruk det første året. Etter to år ruset pasientene i kontrollgruppen seg like mye som før studien, mens de i intervensjonsgruppen fortsatt ruset seg mindre.

Vi ble overrasket over langtidsfunnene, da andre studier har vist effekt stort sett ved kortere oppfølgingstid. Det er viktig med flere behandlingsstudier av personer med psykiske lidelser der oppfølgingen strekker seg over mer enn ett år. En innleggelse kan være en unik sjanse til å gjøre et kortvarig motiverende intervju og hjelpe pasienten til å redusere sin rusmiddelbruk.

\section{Gunnhild Bagøien}

gunnhild.bagoien@ntnu.no

St. Olavs hospital/NTNU

Litteratur

1. Bagøien G, Bjørngaard JH, Østensen C et al. The effects of motivational interviewing on patients with comorbid substance use admitted to a psychiatric emergency unit - a randomised controlled trial with two year follow-up. BMC Psychiatry 2013; 13: 93

\section{Utilstrekkelig legemiddelutprøvning}

\section{Mange legemidler blir ikke til- strekkelig testet før de godkjennes av legemiddelmyndighetene.}

Europeiske og amerikanske retningslinjer anbefaler at legemidler til langvarig bruk testes av 1000-1500 individer og bør utprøves hos minst 300 personer i seks måneder og minst 100 personer i 12 måneder før de godkjennes. Forskere har undersøkt om anbefalingene overholdes (1).

200 nye legemidler, derav 84 til langvarig bruk, som var godkjent av det felleseuropeiske legemiddelverket EMA i perioden 2000-10 ble evaluert. Mediant antall pasienter i studiene var 1708 per legemiddel. Retningslinjene for langtidsutprøvning ble overholdt for $80 \%$ av medisinene til langvarig bruk.
- Selv om regelverket i det store og hele følges, viser undersøkelsen at nye legemidler, uansett indikasjon, evalueres i kliniske studier som gjennomgående inkluderer relativt få pasienter som følges over kort tid, sier Lars Slørdal, professor ved Norges teknisknaturvitenskapelige universitet (NTNU) og overlege ved Avdeling for klinisk farmakologi, St. Olavs hospital. - Dette er tilstrekkelig for å vise at legemidlene har den påståtte effekten, men ofte utilstrekkelig for å vise at legemidlene er trygge. Sikkerhetsaspektet blir enda mer problematisk når vi vet at de pasientene som inngår i slike studier vanligvis skiller seg fra målgruppene, bl.a. ved å være yngre, ikke ha andre sykdommer og ikke bruke andre legemidler. - Få pasienter $\mathrm{i}$ en klinisk studie innebærer økt risiko for ubehagelige overraskelser senere. Den beste måten å beskytte seg mot slikt er å velge «gamle» legemidler med en velkjent effektog bivirkningsprofil. Legemiddelmyndighetene burde dessuten vært mer aktive i rollen som samfunnets dørvokter i legemiddelsikkerhetsspørsmål. I dag ser det ut til at industriens interesser tillegges for stor vekt, sier Slørdal.

\section{Sigurd Høye}

sigurd.hoye@medisin.uio.no

Tidsskriftet

\section{Litteratur}

1. Duijnhoven RG, Straus SM, Raine JM et al. Number of patients studied prior to approval of new medicines: a database analysis. PLoS Med 2013; 10: e1001407. 